УАК 327

ББК 66.4(0)

DOI 10.22394/1682-2358-2021-1-22-28

Liu Yan, post-graduate student of the Political Science Department, Kazan (Volga Region) Federal University

\section{ORGANIZATIONAL FORMS OF STATES' INTERNATIONAL COOPERATION ON THE BLACK SEA ISSUES}

The organizational forms development of interstate cooperation on the Black Sea region issues is investigated. Particular attention is paid to the analysis of organizations established on the basis of international agreements and losing their status due to regional factors.

Key words and word-combinations: Black Sea region, international relations, international organizations.

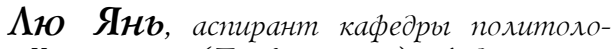
гии Казанского (Приволжского) федерального yнubepcumema (email: sirina_elabuga024@mail.ru, 912144572@qq.com)

\section{ОРГАНИЗАЦИОННЫЕ ФОРМЫ МЕЖАУНАРОАНОГО СОТРУАНИЧЕСТВА ГОСУААРСТВ

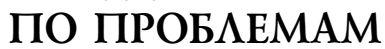 ЧЕРНОГО МОРЯ}

Аннотация. Исследуется развитие организационных форм межгосударственного сотрудничества по вопросам черноморского региона. Особое внимание уделяется анализу организаций, учрежденных на основании международных соглашений и утрачивающих свой статус в связи с региональными факторами.

Ключевые слова и словосочетания: черноморский регион, международные отношения, международные организации.

U

ерное море явцяется зоной соприкосновения национальных интересов разАичных государств, которые стремятся вести собственную политику в отношении прибрежкных вод. ОАнако расширение спектра вопросов, вызывающих обеспокоенность у мирового сообщества, повиияло на развитие некоторых организационных форм сотрудничества причерноморских государств.

Исследователи, как правило, вылемяют три типа межкународных организаций, занимающихся проблемами Черного моря $[1$, с. $115 ; 2$, с. 30]:

22 Bulletin of the Volga Region Institute of Administration • 2021. Vol. 21. № 1 
1) организации, учрежденные в договорном порядке, то есть предусмотренные положениями действующих межгосударственных соглашений;

2) организаџии с общей компетенџией, затрагивающие в том числе отраслевые проблемы Черного моря;

3) неправительственные организации, специализирующиеся на отдемьных направлениях развития Черноморского региона.

В приведенной типологии прослеживается учредительный критерий той или иной формы организационного сотрудничества, который, в свою очередь, критикуется отдельными авторами как архаичный подхоА, не отвечающий современным тенденциям [3]. Вследствие такой оџенки преАмагается брать за основу классификации международных организаџий, занимающихся вопросами Черного моря, степень их влиятельности [4, c. 86; 5]. Схожей позиции придерживаются ученые, разрабатывающие проблемы эффективности решений, принимаемых в определенных организационных формах межкосударственного сотрудничества [6] .

Так или иначе ключевым условием формирования международных отношений остается договорный характер учреждения подобных организаций, который вместе с тем далеко не всегда гарантирует долговечность существования координационных наднациональных органов, как это произошло с Комиссией по межАународным проливам, осушествлявшей свою деятельность на основе Аозаннской конвенции. Преемником данной организации явицось национальное правительство Турецкой Республики, которое в силу положений Конвенции Монтре о статусе проливов 1936 г. приобрело исключительные полномочия по управлению черноморскими проливами.

Аналогичным образом не выделяется специальная организационная форма в Соглашении о сотрудничестве причерноморских государств при поиске и спасении на Черном море 1998 г. [7]. ЕАинственной организацией, обладающей по данному договору функщией межгосударственной координаџии, служит конференџия с участием официальных преАставитемей государств-чменов этого Аоговора. Примечательно, что подобные формы международных организаџионных структур практически не получили научного осмысления среди современных исследоватекей.

Такое обстоятельство обосновано тем, что многие формы международного сотрудничества по вопросам Черного моря сушествуют на непостоянной основе, в силу чего сложно проанализировать их институщиональные признаки. Кроме того, некоторые из подобных форм фактически безАействуют в силу целого ряда внешнеполитических факторов. Примером этому может служить ситуация с деятельностью Комиссии по вопросам рыболовства в Азовском море, созданной между Россией и Украиной еще в 1993 г. на основании специального соглашения [8]. В 2018 г. быми сорваны очередные плановые переговоры на базе данной организационной формы в связи с продолжающимся конфликтом двух государств. ОАнако 
уже в начаме 2019 г. квоты на вылов рыбы получили согласование дистанционным способом со стороны как Российской Федерации, так и Украины. Следует отметить, что добиться договоренности удалось уже без применения площадки Российско-Украинской Комиссии, то есть напрямую межАу органами исполнительной власти двух государств.

Еще одним уникамьным примером организаџионной формы межгосударственного взаимодействия является Организация черноморского экономического сотрудничества. Несмотря на то, что одноименный межАународный договор [9] подписан межАу странами, включая Российскую Федерацию, еще в 1992 г., Аанная наднациональная структура была созАана цишь в 1999 г. Это объясняется тем обстоятельством, что в тексте соглашения 1992 г. получили закрепление только регулярные встречи министров иностранных дел стран-участниц. Статус же Организации черноморского экономического сотрудничества определен так называемым «Босфорским заявлением», слеланным дважды - в 1992 и 1999 гг. В промежуток между указанными датами, в 1994 г., появияся Секретариат буАущей межАународной организации.

K современному этапу своего развития Организация черноморского экономического сотрудничества иниџиирует подписание специальных межгосударственных соглашений, направленных на решение проблем Черного моря. Так, в 2017 г. в Стамбуле была утверждена Аекларация 25-го юбимейного саммита Парламентской Ассамбцеи, в которой государства-участники подтвердици свои международные обязательства и сформулировали позиџию по новым вызовам - в частности, по миграционному кризису, внедрению передовых технологий, противодействию терроризму и организованному криминалу, использующих черноморские транспортные пути, и Аругим.

Примечательно, что в рамках указанной Аекларации обозначены новые организационные формы сотрудничества в виде рабочих групп, состоящих не только из офиџиальных преАставителей власти кажАого государства-участника, но и из экспертов в определенной обцасти (энергетики, банковского сектора, экологии и Ар.). Акцент на усиление переговорных процессов через подобные формы продиктован разрастанием конфликтов, в том числе в экономической сфере между странами-участницами Организации черноморского экономического сотрудничества. При этом в условиях снижения межгосударственной активности в двухстороннем порядке использование площадок в виде рассматриваемой организационной формы выступает еАва $\Lambda и$ не единственным способом достижения компромиссов.

Аругой межАународной правительственной организаџией, соприкасающейся с вопросами использования акватории Черного моря, является Комитет по контролю судов в Черноморском регионе, который был учрежден на основании одноименного Меморандума 2000 г. [10]. Он

24 Bulletin of the Volga Region Institute of Administration • 2021. Vol. 21. № 1 
состоит из представителей государств-участников, а также делегатов из Международной морской организации и Международной организации труда. Последние две наАнациональные структуры не имеют права голоса при принятии решений в рамках Аанной организационной формы.

Особенностью деятельности данного Комитета служит комплекс контрольных полномочий, а также координация проверочных мероприятий на ежегодных заседаниях, которые фактически проводятся каждые пятьшесть месяцев. Секретариат данной международной региональной организации располагается в Стамбуле, а сессии осуществмяются в крупнейших городах Черноморского региона (Одессе, Батуми, Бургасе и др.).

Вместе с тем Комитет по контролю судов в Черном море фактически реализует мишь половину мер, предусмотренных Меморандумом 2000 г. Подобное состояние вызвано рядом конфциктов межАу странами-участницами Аанного согмашения - например, межжу Болгарией и Турџией, Россией и Грузией, Россией и Украиной. Тем самым функции рассмат-

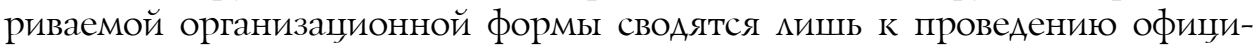
альных встреч, на которых делаются попытки выработать общие наднационацьные стандарты контромя над морскими судами в Черноморском регионе. ОАнако к настоящему моменту ни одного нормативно-правового акта, разработанного на базе Комитета по контролю судов в Черном море, не принято, что осложняет процесс воплощения принџипов Меморандума 2000 г.

Помимо межаународных организаций, имеющих специальные компетенции по вопросам Черного моря, активную деятельность в Аанном направлении осуществляют другие региональные наднациональные структуры. Так, Европейский союз рассматривает Черное море как часть своих внутренних морских территорий. Еще в 2011 г. его институты приняли резолюцию, утверждающую текст специальной Черноморской стратегии [11]. В ней выделены три кмючевых направления, в которых ЕС выражкает интересы своих государств-членов: безопасность, включая экологию; энергетико-транспортный сектор и социально-экономическое развитие населения стран, имеющих выход к Черному морю.

Примечательной особенностью Аанного Аокумента явцяется прямое закрепление угроз его воплощению в виде нахождения российских баз на полуострове Крым. Аналогичного подхода к размешению баз США на территории, например, Румынии, в Черноморской стратегии ЕС не прослежииалось.

Ужке в 2015 г. представители ЕС стали делать заявления о необходимости кардинального пересмотра стратегических решений по Черному морю в связи с меняющимися геополитическими и регионацьными условиями его использования [12]. Вместе с тем акџент в Аальнейшем развитии европейской политики сАелан не на безопасность, а на экономические и экологические вопросы развития Черноморского региона. 
Европейский союз считается одной из международных организаций, делающих упор на максимальное расширение научных исследований Черного моря. В Аитературе отмечается, что подобная тактика может расцениваться в качестве политики «мягкой силы», направленной на решение задач в Черноморском регионе [13, с. 110]. При этом критическое отношение к внешней политике Российской Федерации со стороны ЕС стало более наглядным с 2014 г. В частности, миквидация такой организаџионной формы сотрудничества, как стратегическое партнерство между Европейским союзом и Российской Федерацией, привека к ситуации, в которой институты ЕС сегоАня не имеют прямой возможности обсужАать проблемы Черного моря непосредственно с российской стороной. Это возможно мишь через межАународные связи отдельных государств-членов ЕС, а также через существующие региональные международные организации, занимающиеся черноморской повесткой.

Тем не менее следует признать отдельные площадки ЕС в качестве специальных организационных форм межгосударственного сотрудничества по Черному морю. Наличие членства в ЕС у Болгарии и Румынии, а также обязательства по ассоџиации с Украиной и Молдовой позволяют рассматривать ЕС в качестве одного из акторов черноморской политики.

Кроме организационных форм международного взаимодействия по вопросам Черного моря с участием конкретных государств, сложились и отдельные неправительственные организаџии, специализирующиеся на выстраивании внешних связей с Аругими акторами Черноморского региона. К сожалению, таких структур недостаточно, чтобы комплексно решать проблемы безопасности, экологии и транспортно-экономических связей в Черном море. ОАнако некоторые из них претендуют на особый региональный статус. Например, на территории Республики Крым активно функционирует Черноморская ассоџиация межАународного сотрудничества (ЧАМС), созданная в 2016 г. Аанное транснациональное общественное объединение демонстрирует попытку расширения интеграционных процессов в условиях особого санкџионного режима, установменного в отношении Крыма и Российской Федераџии со стороны џелого ряда государств и межАународных организаций.

ЧАМС явмяется членом Аругой, более крупной неправительственной структуры - Российской ассоциации международного сотрудничества. ОАнако, помимо ориентации на российские интересы, данное объединение имеет связи с неправительственными структурами Турџии, Болгарии, Абхазии, а также участвует во многих международных форумах и конференциях, проводимых преАставитемями организаций, преимущественно молодежных, из разных государств по пробцемам Черного моря. При этом ЧАМС позищионирует себя в качестве плошадки, которая может проводить различные мероприятия непосреАственно на территории Крыма, минуя установленные международные санкции.

26 Bulletin of the Volga Region Institute of Administration • 2021. Vol. 21. № 1 
Более опытной следует признать такую неправительственную организацию, как Межкународный черноморский клуб. Кроме проведения общественных мероприятий, данная структура является наблюдателем в Организации черноморского экономического сотрудничества, что позвомяет ей устанавливать прямые контакты с государствами - членами этого объединения. Она имеет также консультативный статус в Экономическом и соџиальном комитете ООН, что способствует повышению ее авторитета при построении международных связей. ОАнако после 2014 г. данная организация фактически мишилась четверти своих чиенов - портовых городов Черного моря в связи с обострением конфликта между Российской Федерации и Украиной. К настоящему моменту не участвуют в ее Аеятельности организации из Абхазии и Крыма.

Таким образом, необходимо констатировать, что сложившаяся в науке кмассификация организационных форм международного сотрудничества по вопросам Черного моря значительно трансформировалась. Отход от деятельности организаций, созданных на базе межгосударственных соглашений, привел к усияению двухстороннего взаимодействия между странами с участием непостоянных и неинституџионализированных пиощадок.

Именно поэтому доминирование учредительного критерия в типомогии форм межкгосударственного взаимодействия следует признать устаревшим трендом. Поскольку все больше организационных форм таких взаимоотношений по вопросам Черного моря имеют динамичный характер, их институџиональные признаки находятся в стадии своего формирования. Напротив, некоторые из рассмотренных организаций фактически бездействуют по причине отсутствия у них надлежащих полномочий, гарантированных государствами. В сику этого преАлагается классифицировать организационные формы международного сотрудничества в Черноморском регионе в зависимости от их возможностей на организаџии, учрежденные международными договорами на постоянной основе и подАерживаемые государствами-чменами; внешние организации, создающие спеџиальные площадки по взаимодействию государств по отраслевым проблемам Черного моря; неправительственные организащии, специализирующиеся на отдельных направлениях развития Черноморского региона.

\section{Библиографический список}

1. Guavik A. Regional in the Black Sea basin // Economie si Sociologie: Revista TeoreticoStiintifica. 2015. № 2. C. 113-117.

2. Семенишин М.В. Проблемы институционного сотрудничества стран региона Черного моря // Социально-гуманитарный вестник Юга России. 2012. № 1 (21). С. 29-31.

3. Эшба Э.Д. Региональное сотрудничество на Черном море: достижения, проблемы, перспективы // Вестник МГИМО Университета. 2013. № 6 (33). С. 42-48. 
4. Белякова Н.С. Роль и место Черноморского региона во внешней политике Турецкой Республики на современном этапе: дис. ... канд. полит. наук. М., 2015.

5. Ходоченко A.B. Черноморский регион: развитие сотрудничества в энергетическом секторе между странами ОЧЭС // Kant. 2020. № 1 (34). С. 111-115.

6. Календжян С.О., Скляренко Р.П. Динамика экономик стран - членов Организации черноморского экономического сотрудничества // Международный научный журнал. 2019. № 6. C. 103-110.

7. Соглашение о сотрудничестве причерноморских государств при поиске и спасании на Черном море (г. Анкара, 27 нояб. 1998 г.). Документ вступил в силу для России 24 апр. 2010 г. // Бюллетень международных договоров. 2011. № 8.

8. Соглашение между Комитетом Российской Федерации по рыболовству и Государственным комитетом Украины по рыбному хозяйству и рыбной промышленности по вопросам рыболовства в Азовском море 14 сент. 1993 г. // Министерство иностранных дел РФ; Министерство иностранных дел Украины, Россия - Украина. 1990-2000. Документы и материалы: в 2 т., 1990-1995 гг. М., 2001.

9. Декларация о черноморском экономическом сотрудничестве 25 июня 1992 г. // Дипломатический вестник. 1992. № 13-14.

10. Меморандум о взаимопонимании о контроле судов со стороны государства порта в регионе Черного моря от 7 апр. 2000 г. // Транспорт России. 2015. № 37.

11. EU Strategy for the Black Sea (2010/2087ONI). URL: https://www.blackseanews.net/ $\mathrm{read} / 10041$

12. Европейская комиссия за всеобъемлющую стратегию ЕС по Черноморскому региону. URL: https://ria.ru/20150610/1069297320.html

13. Узнародов Д.И., Узнародов И.М. Политика Европейского союза в Черноморском регионе в контексте отношений с Россией // Известия вузов. Северо-Кавказский регион. Сер.: Общественные науки. 2018. № 2 (198). С. 108-116.

28 Bulletin of the Volga Region Institute of Administration • 2021. Vol. 21. № 1 